\title{
worldview
}

A JOURNAL OF RELIGION AND INTERNATIONAL AFFAIRS

LATIN AMERICAN DIARY

SETH TILLMAN

WARS WILI OCCUR AS LONG AS...

GORDON ZAHN

\section{CONFRONTING OUR}

EUROPEAN CHRISTIAN HERITAGE

EDWARD T. GARGAN

\section{THE MIDDLE EAST AND VIETNAM}

We did not need the additional evidence, but much of the discussion which swirled around the Mideast crisis during early June confirmed the sad state of general political debate.

During the long and continuing debates on Vietnam many people had grown accustomed to using certain arguments, concepts and terms as if they had clear and universal application. But when they found that the same arguments and concepts, applied to the Israeli-Arab conflict, could lead them to conclusions they regarded as unpalatable, they were bewildered. Some of the "peace movement" journals continue to print anguished letters from people whose recent certainties are now overthrown. Scales of innocence have dropped from their eyes; they have, in their terms, gazed on evil clearly; they can no longer discern that pure path which once had seemed to cut so neatly through the complexities of international affairs. For some of these people it is the end of what they had regarded as positive political activity; for others it is the beginning of political education.

To note these facts is not to mock the people involved. As many of them readily acknowledge, they are exceedingly vulnerable. Innocent of serious political theory and untested by history, they formed and raised their arguments unsystematically on premises too narrow to long support them. One cannot, they learned, extrapolate from Vietnam to all other international conflicts.

But if allowance can be made for those who are politically naive and untutored, what can be said about the confusion of others - leaders in our society - whose experience and authority admit no such allowance? For the confusion is evident among experts who defend and experts who criticize U.S. policy in Vietnam. It is reported, for example, that John P. Roche, a special Presidential consultant, referred sarcastically to those who oppose present U.S. intervention in Vietnam but who wished the U.S. to intervene in the Arab-Israeli crisis as "doves for war." Intended as anything more than an obvious and irrelevant joke, such a comment is intellectually contemptible. It refuses to recognize that different political realities require different political action and that, excepting the consistent pacifist, one may see armed intervention justified in 
some cases but not in others.

The conf usion was most clearly revealed in the statement of Arthur Schlesinger, Jr, who refused to sign a statement urging U.S. intervention in the Middle East crisis saying, "I think it inconsistent to favor unilateral intervention in one part of the world when I'm atready opposed to milateral intervention in another part of the world." And, possibly recognizing this as a not wholly sutisfactory statement, he was impclled to the desperate straits of adding that his views on the Middle East were nobody's business.

The comments of Messrs. Roche and Schlesinger suggest - although the contrary must surely be the case - that they believe some single principle cau be as sufficient criterion for decision in circumstances of the most varied complexities. But there is no universal political solvent that will dissolve all messy situations, no single political touchstone that will discriminate between the just and the unjust conflict, the justifiable and the unjestifiable intervention.

Most people speak in favor of peace; war is no longer regarded as a laudable enterprise. But most pcople also speak in favor of justice. And surely only the politically obtuse can continte to speak and act as if the two never come into contlict. Ant when they do, no resolution can ignore those historical particulars which vary in every situation.

In his approach to a definition of "interven- tion," Manfred Halpern has written: "We live at at time when intervention, by subverting the sovereignty of national independence, may further undermine the only rules of the game that now maintain order, yet when only intervention may be able to restore the free operation of these rules, save freedom in a nation or, indeed, help to create a more secure and more frecly interdependent world order. In our world, intervention ean he moral or immoral, or simultaneously illegal and justifiable. The morality of intervention is determined both by the principles it creates or destroys and by the contingencies of circumstances. Intervention therefore involves a realm of morality in which a discussion of principles is essential but in which no discusssion of principles has relevanec for the next act of intervention or nonintervention until the circumstances surrounding that act have also been discussed."

What has been absent in mich of our political debate is a sense of the relation between neerssarily abstract principles and the "contingencies of circumstances." This absence is a fliw which, apparently, cuts across all levels of political discussion. In the discussion of any subject we should expect no greater clarity than the sulject itself allows. But it would be melancholy to conclude that we cannot surpass the level we have atteined in our discussion of the Mideast conflict.

\section{in the magazines}

Richard S. Hartigan, in "Noncombatant Immunity: Refections on Its Origins and Present Status" (The Re- vieu of Politics, April), advances the thesis "that the role of civilinin immatity achieved its present form primarily as the result of long custom and practice, and only secondarily as the result of deductive moral reasoning," and that "this, in turn, means that the cthical prohibition against slaying the imnocent intentionally may not be perfectly congruent with the practical rule that distinguishes between civiljans and armed forces." In support, he offers a review of the philosoph- ical and historical development of the principle of civilian immunity, and concludes that "instcad of enshrining this relative and expediential norm with an absoluteness that it does not and was never intended to possess, it may be recognized for what it is : a juridical determination that has its roots in customary development and expression and that in a past age was casily identifiable with an accepted ethical nom. If today its inherent practicability as a rule of limitation in modern warfare is doubtful, then cither it ought to be re-examined carefully in order to nake it applicable 